\title{
ASSESSING THE SUSTAINABILITY OF GRAZING IN PROTECTED NATURAL AREAS BY MEANS OF THE ANP: A CASE STUDY IN THE COTOPAXI NATIONAL PARK (ECUADOR).
}

\author{
Wilson Jácome-Enríquez* \\ Construction and Earth Sciences Department, Escuela Politécnica del Ejército \\ Avenida General Rumiñahui s/n, Sangolquí, Ecuador \\ E-mail: wojacome@espe.edu.ec \\ Tomás Gómez-Navarro ${ }^{1}$ \\ Departamento de Proyectos de Ingeniería \\ Universitat Politècnica de València. Valencia. Spain \\ E-mail: tgomez@dpi.upv.es \\ Ricardo Pachamama-Méndez \\ Escuela Politécnica del Ejército \\ Avenida General Rumiñahui s/n, Sangolquí, Ecuador \\ E-mail: rfpachacama@espe.edu.ec
}

\begin{abstract}
The protected natural areas of Ecuador face several environmental threats; grazing is one of them in several national parks (NP) including the Cotopaxi National Park (CNP). National Park managers are proposing action alternatives to reduce grazing environmental impact while promoting social and economic development of cattle ranchers and the other stakeholders. For the success of any of these actions, as much consensus as possible is needed among all involved stakeholders.

In this paper, the Analytical Network Process (ANP) is used to modeling the decision problem and helping stakeholders to participate assessing the sustainability of the solution alternatives. In the presented methodology, a panel of experts in natural areas management was arranged to determine the decision model i.e. the network of criteria and alternatives structured into clusters. Ten criteria were set in 6 clusters: 3 environmental -atmospheric, soil and water contamination-, 1 social, 1 economic and 1 cluster of alternatives. The alternatives, included in the revision of the NP management plan, were: Physical delimitation of the park and control of the entering livestock, Development of productive alternatives to grazing, and Pasture subsidies.

The findings confirm that stakeholders hold different interests, approaches to sustainability and sensitivities. After ANP all stakeholders understand better their interests and the others'. Thus, an improved participation is obtained and consensus or at least general agreements are more likely. Also a better commitment to the overall objective is achieved as the decision model facilitates improving the alternatives design in order to lessen the possible burdens for specific stakeholders or the environment.
\end{abstract}

Keywords: Analytic Network Process (ANP), Natural Park management, Grazing.

\footnotetext{
${ }^{*}$ Corresponding author

1 Acknowledgment: The research presented in this paper has been funded by the Centro de Cooperación al Desarrollo of the Universitat Politècnica de València by means of the ADSIDEO program.
} 


\section{Introduction}

The Cotopaxi National Park (CNP) is placed in the Andes Cordillera, in the provinces of Cotopaxi, Pichincha and Napo, $60 \mathrm{~km}$ to the south of Quito (Ecuador). In this park, the highest mountain is de Cotopaxi volcano (5987 meters above sea level). According to Coello (2007), this park is constituted by grazing area $(60,47 \%)$, snow or ice $(22,82 \%)$, rocks $(13,41 \%)$ and short period crops (corn) and forest plantations $(3,30 \%)$. Nowadays, the CNP is one of the main touristic attractions in the country, visited by approximately 120.000 tourists per year: foreigners $(57 \%)$ and local tourists $(43 \%)$, who mostly visit the Cotopaxi volcano.

This natural area faces several environmental problems, which must be solved through participatory management, in order to fulfill the conservation objectives of the ecosystems and the natural resources of this area. The main environmental problems identified in the CNP are the following: grazing, burning of grazing areas, illegal hunting and fishing, and erosion.

The problem of overgrazing in the CNP is well known (Pugh y Sarmiento 2004). Despite of all undertaken activities, there are no consensual actions to satisfy the different actors, and some of them feel that neither their interests are taken into account, nor they know the interests of the other actors (Busch y Silva 2006).

In the solution of the different environmental, social and economic problems, the Multi-Criteria Decision Aids (MCDA) have demonstrated to be very helpful tools, especially the Analytical Network Process (ANP), the one proposed for modeling one most important problem of the CNP: grazing. Hence, this paper presents the application of the Analytical Network Process (ANP) to modeling the decision problem and helping stakeholders to participate assessing the sustainability of the solution alternatives to overgrazing in CNP. It is very important to count on the participants who are involved throughout the evaluation and interpretation processes and use of the results. Therefore, the aim of this proposal is not to substitute the work of any of the environmental assessment experts, but on the contrary, to ease and facilitate it. The experts' opinions and judgments are the only ones to be taken into account and to be the input data in the evaluation model.

\section{The use of ANP for the assessment of environmental problems}

The Analytic Network Process (ANP) is a method proposed by Saaty (2001). It provides a framework for dealing with decision making or evaluation problems. It presents its strengths when working in scenarios with scarce information. ANP generalizes the problem modeling process using a network of criteria and alternatives (all called elements), grouped into clusters. All the elements in the network can be related in any possible way, i.e. a network can incorporate feedback and interdependence relationships within and between clusters. This provides an accurate modeling of complex settings and allows handling the usual situation of interdependence among elements in environmental assessment scenarios.

Some of the recent applications involving ANP are found in strategic policy planning (Erdoğmuş et al., 2006); forest management (Partovi and Corredoira, 2002); Local Agenda programmes priotisation (PerisBlanes et al., 2011) or environmental pressure assessment (Gómez-Navarro et al. 2009).

\section{Methodology}

\subsection{Analytic Network Process (ANP)}

Details on the Analytic Network Process (ANP) can be found in Saaty (2001), however, the main steps are summarized here for completeness. 
(i) Pairwise comparisons on the elements and relative weight estimation

(ii) Construction of the original supermatrix (unweighted supermatrix)

(iii) Constructing the weighted supermatrix

(iv) Calculation of the global priority weights

\subsection{Flowchart of the study}

In this research, the ANP method was used to design the decision making model. The aim was to establish the main strategies to resolve the problem of grazing in order to support the Cotopaxi National Park administration to carry out a successful management. This research was divided in two levels: the first level was intended to identify the criteria involved in the decision making about the grazing, and then to design the decision making model. The second level was intended to promote the participation of the main stakeholders in order to select and prioritize the solution alternatives according to the satisfaction of their interests. In the Figure 1, the methodology is described through the main steps, which led the present research.

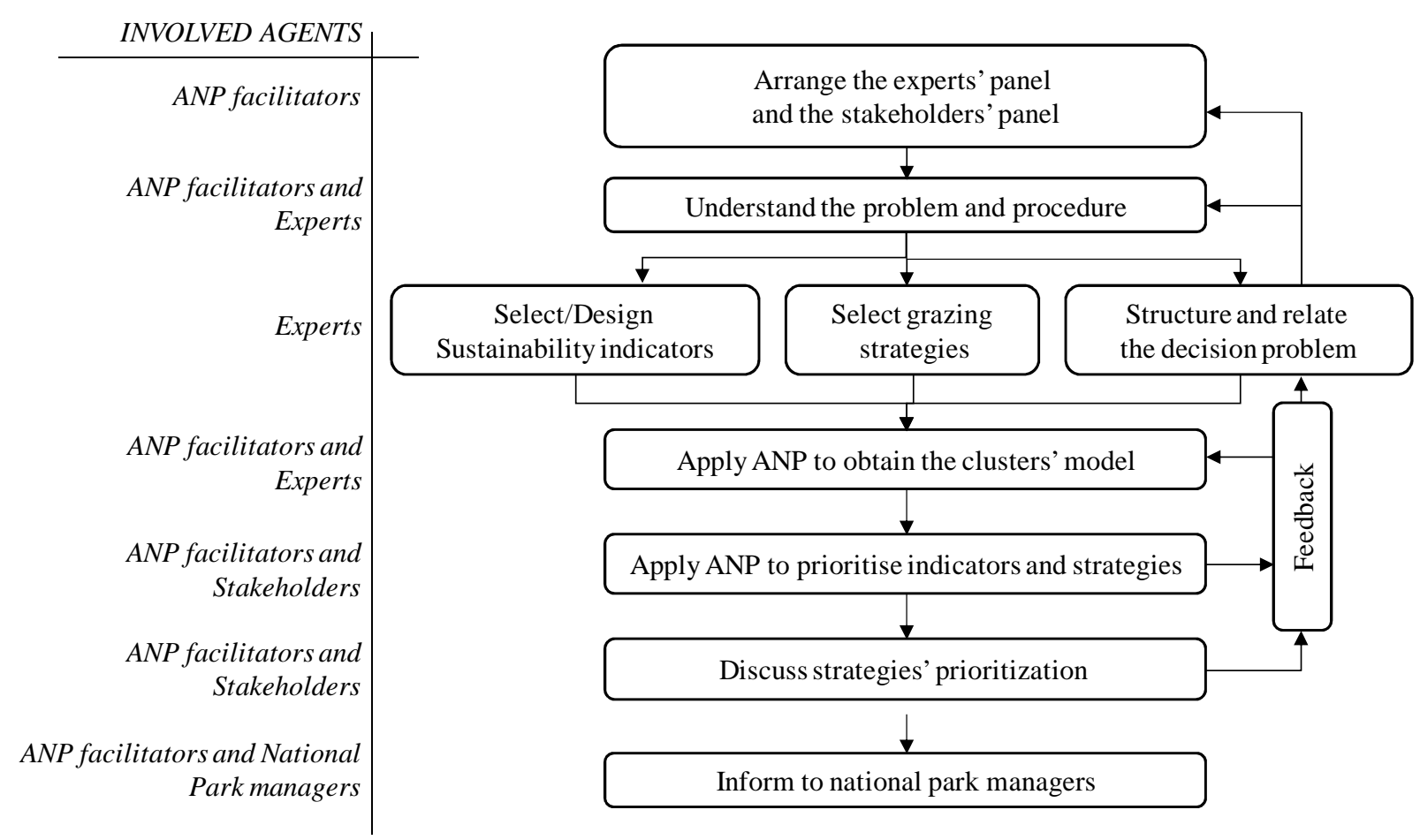

Figure 1. Research methodology.

There were three groups of implicated agents: (i) facilitators of the ANP process (authors of this research), (ii) experts' panel to model the assessment problem, and (iii) stakeholders related to the national park in order to assess the model with the criteria and solution alternatives for the grazing problem. The two experts selected the ANP elements and designed the decision model, i.e. the correlation matrix (see Table 1):

- One expert in natural resources sustainable management. He is a Geographic Engineer and MSc in Environmental Geography, with several national and international postgraduate courses. Besides, this expert has been university professor on Environmental Impact Assessment and Natural Resources Management, during the last 15 years. 
- One expert in protected natural areas management, who is an Engineer in Ecotourism and Natural Areas Conservation, with wide experience in natural areas management due to his works in the planning and administration of natural parks and ecological reserves of Ecuador.

\subsection{Clusters and criteria}

According to the literature review and the experts' proposals the assessment criteria are:

\section{CLUSTER 1: SOIL DEGRADATION}

C1: Erosion: it is produced by the livestock footprints, which deteriorate de soil structure, leaving the soil exposed to different types of erosion such as: laminar, hydro and wind erosion (Nunes et al. 2011; Blanco Sepúlveda y Nieuwenhuyse 2011).

C2: Soil compaction: it is produced by intense footprints of livestock, this makes the soil loses its structure and texture, and becomes compacted (Quiroga et al. 2009; Blanco Sepúlveda y Nieuwenhuyse 2011).

C3: Loss of vegetation cover: it is produced by the livestock footprints, which do not allow the growing of mew plants of pasture, herbs and grasses. Also it is due to the livestock feeding process that requires a lot of pasture and forage herbs. All of this makes the high altitude Andean plants (pasture and forage herbs) lose their diversity and abundance, leaving the soil unprotected (Agnoletti 2007; Teague et al. 2011).

\section{CLUSTER 2: WATER CONTAMINATION}

C4: Surface water contamination: it is produced by livestock excrements, which are dragged toward water bodies (creeks, rivers, lakes). All of this produces water contamination by organic and inorganic chemical compounds (Strauch 2009).

C5: Underground water contamination: it is produced by filtration of the contaminants from de livestock excrements (Nautiyal y Kaechele 2007; Strauch 2009).

\section{CLUSTER 3: ATMOSPHERIC CONTAMINATION}

C6: Atmospheric emissions due to pasture burning: these emissions are produced by pasture burning generated by the cattle raisers in order to obtain new herbs to feed the livestock. This practice is common among the herdsman from the Andes region. These pasture burnings produce greenhouse gases such as carbon dioxide $\left(\mathrm{CO}_{2}\right)$ and also particulate matter like soot and ashes (Savadogo 2007; Solomon et al. 2007).

\section{CLUSTER 4: OWNERSHIP RIGHTS AND LIMITS}

C7: Land ownership: the grazing is tightly related to the problem of land ownership of some cattle ranches inside the park. Thus, some herdsmen think that grazing inside the park is their right. Besides, other herdsmen who do not have any land ownership inside the park cross the limits of the park with their cattle in order to graze (Himley 2009; Solomon et al. 2007).

C8: Delimitation of the park: this problem is directly related to the grazing due to the absence of the physical delimitation of the park. Hence, some cattle raisers invade the park to carry out grazing activities (Busch 2006; Himley 2009).

\section{CLUSTER 5: SOCIOECONOMIC ASPECT}

C9: Job opportunities and incomes: grazing is an economic activity of the communities living in the Andean páramos (high altitude andean grassland). With this economic activity, the local communities get most of their incomes to live. Therefore, it is necessary to diversify the job opportunities in order to get 
incomes from other economic activities by using the CNP natural resources in a sustainable way (Barkmann et al. 2008; López-i-Gelats et al. 2011)

C10: Pastoral tradition: local communities have conducting grazing activities in the Andean pastures for centuries (MacLeod y McIvor 2006; Williams 2011).

CLUSTER 6: STRATEGY ALTERNATIVES.

A1. Physical delimitation of the park and livestock entering control: In order to solve overgrazing in the park, it is necessary to control the entering of livestock as well as to build a physical boundary in the most vulnerable zones.

A2. Productive projects opportunities: To diminish or eliminate overgrazing, it is necessary to establish job opportunities and alternative sources of incomes for the local communities, through the development of sustainable community projects (Reed et al. 2006).

A3. Pastures subsidy: In order to avoid overgrazing within the park, it is necessary to supply pastures for livestock at no cost, which would be subsidized by the Ecuadorian government.

\subsection{The decision problem model}

According to the experts the correlation matrix is set as shown in Table 1. The network model is as shown in Figure 2.

Table 1. Correlation Matrix.

\begin{tabular}{|c|c|c|c|c|c|c|c|c|c|c|c|c|c|c|}
\hline \multirow[b]{2}{*}{ CLUSTERS } & \multirow{2}{*}{$\begin{array}{l}\text { CLUSTERS } \\
\text { ELEMENTS }\end{array}$} & \multicolumn{3}{|c|}{ 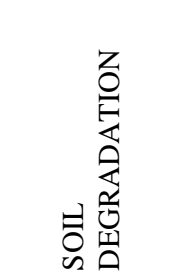 } & \multicolumn{2}{|c|}{ 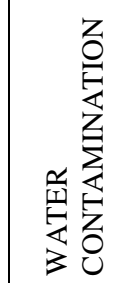 } & \multicolumn{2}{|c|}{ 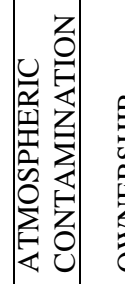 } & 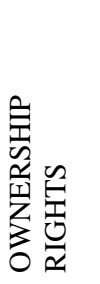 & \multicolumn{2}{|c|}{ 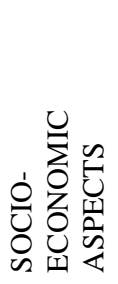 } & \multicolumn{3}{|c|}{ 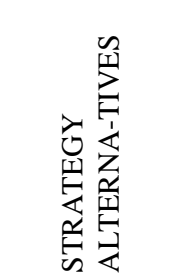 } \\
\hline & & 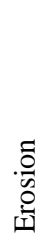 & 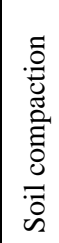 & 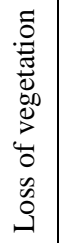 & 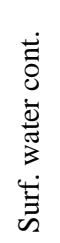 & $\begin{array}{l}\dot{\tilde{J}} \\
\dot{0} \\
\dot{3} \\
\dot{0} \\
\dot{\Xi} \\
\dot{0} \\
\dot{0}\end{array}$ & 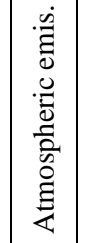 & 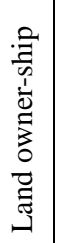 & 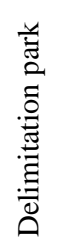 & 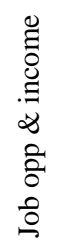 & 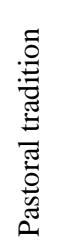 & Z & $\frac{1}{4}$ & 2 \\
\hline \multirow{3}{*}{$\begin{array}{l}\text { SOIL } \\
\text { DEGRADATION }\end{array}$} & Erosion & & 0 & 1 & 1 & 0 & 0 & 0 & 0 & 1 & 0 & 1 & 1 & 1 \\
\hline & Soil compaction & 1 & & 1 & 1 & 0 & 0 & 0 & 0 & 1 & 0 & 1 & 1 & 1 \\
\hline & Loss of vegetation cover & 1 & 1 & & 1 & 0 & 0 & 0 & 0 & 1 & 0 & 1 & 1 & 1 \\
\hline \multirow{2}{*}{$\begin{array}{l}\text { WATER } \\
\text { CONTAMINATION }\end{array}$} & Surface water contam. & 0 & 0 & 0 & & 1 & 0 & 0 & 0 & 1 & 0 & 1 & 1 & 1 \\
\hline & Underg. water contam. & 0 & 0 & 0 & 1 & & 0 & 0 & 0 & 0 & 0 & 1 & 1 & 1 \\
\hline $\begin{array}{l}\text { ATMOSPHERIC } \\
\text { CONTAMINATION }\end{array}$ & Atmospheric emissions & 1 & 1 & 1 & 1 & 0 & & 0 & 0 & 1 & 0 & 1 & 1 & 1 \\
\hline \multirow{2}{*}{$\begin{array}{l}\text { OWNERSHIP } \\
\text { RIGHTS }\end{array}$} & Land ownership & 0 & 0 & 0 & 0 & 0 & 0 & & 0 & 1 & 1 & 1 & 1 & 1 \\
\hline & Delimitation of the park & 0 & 0 & 0 & 0 & 0 & 0 & 1 & & 1 & 1 & 1 & 1 & 1 \\
\hline \multirow{2}{*}{$\begin{array}{l}\text { SOCIO-ECONOMIC } \\
\text { ASPECTS }\end{array}$} & Job opp. and incomes & 0 & 0 & 0 & 0 & 0 & 0 & 0 & 0 & & 1 & 1 & 1 & 1 \\
\hline & Pastoral tradition & 0 & 0 & 0 & 0 & 0 & 0 & 0 & 1 & 1 & & 1 & 1 & 1 \\
\hline STRATEGY & A1 & 1 & 1 & 1 & 1 & 1 & 1 & 1 & 1 & 1 & 1 & 0 & 0 & 0 \\
\hline
\end{tabular}




\begin{tabular}{|c|c|c|c|c|c|c|c|c|c|c|c|c|c|c|}
\hline \multirow[t]{2}{*}{ ALTERNATIVES } & A2 & 1 & 1 & 1 & 1 & 1 & 1 & 1 & 1 & 1 & 1 & 0 & 0 & 0 \\
\hline & A3 & 1 & 1 & 1 & 1 & 1 & 1 & 1 & 1 & 1 & 1 & 0 & 0 & 0 \\
\hline
\end{tabular}

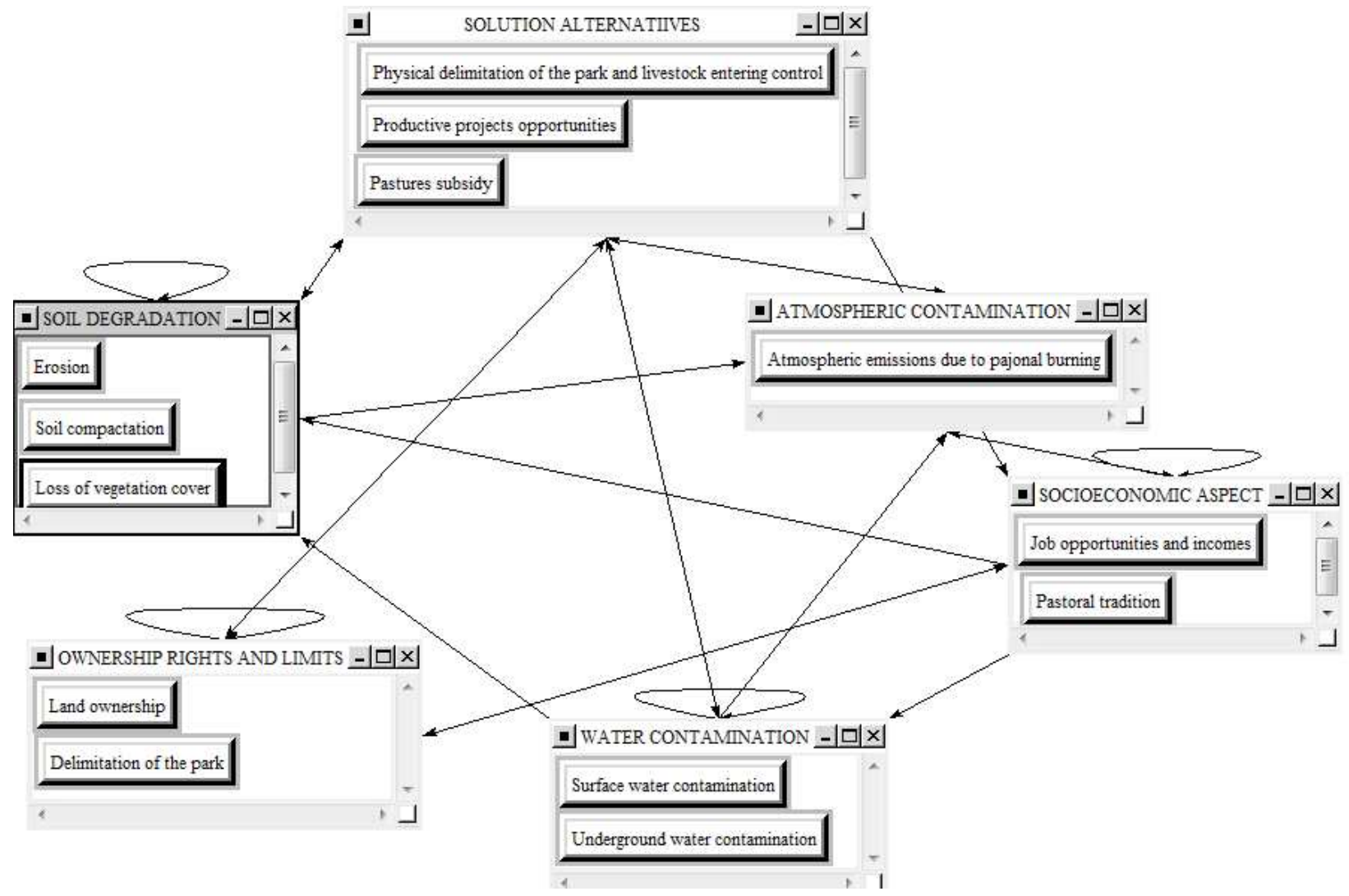

\subsection{Selection of the stakeholders}

Figure 2. Network model of the problem.

After making an analysis of all stakeholders related to the CNP, 15 agents were firstly listed to be analyzed according their interests and influence in grazing issues. Afterwards, a final list was established with 7 stakeholders, who are the most involved agents in the management of the park and have enough knowledge about grazing in protected areas; those are the following:

a) Authorities: CNP parkguard

b) Tourist operator: a representative

c) Tourist: a representative

d) Local communities: Two representatives were selected: one is a cattle raiser. The other one is a neighborhood leader

e) Science: Two university experts were selected: one expert in natural areas management. The other expert is an environmental researcher with several published scientific papers about the Cotopaxi volcano

Thus, the group of stakeholders was formed by 7 people, who are the main representatives from the related agents of the park, whose influence is critical at the moment of taking decisions about the management of this natural area. 


\section{Results of the study}

4.1 Criteria and alternatives weights (preferences)

According to the stakeholders the Limit Supermatrix by stakeholder and, the Limit Supermatrix with aggregated results are shown in Table 2. Prioritizations of the different stakeholders were aggregated by means of the geometric mean according to Saaty's proposal (Saaty, 2001), Accordingly, criteria ranking are shown in figure 3 (Note: values have been normalized in two general groups: Alternatives and Criteria).

Table 2. Aggregated Limit Supermatrix.

\begin{tabular}{|c|c|c|c|c|c|c|c|c|c|}
\hline CLUSTERS & ELEMENTS & 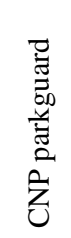 & 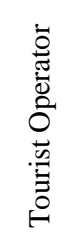 & 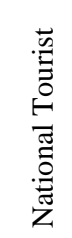 & 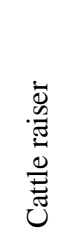 & 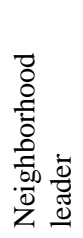 & 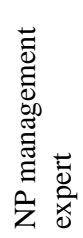 & 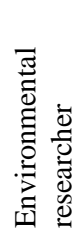 & 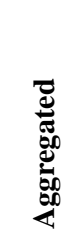 \\
\hline \multirow{3}{*}{$\begin{array}{l}\text { SOLUTION } \\
\text { ALTERNATIVES }\end{array}$} & Physical delimitation... & 0,17 & 0,31 & 0,68 & 0,08 & 0,24 & 0,78 & 0,46 & 0,37 \\
\hline & Productive projects & 0,65 & 0,63 & 0,24 & 0,69 & 0,28 & 0,15 & 0,26 & 0,44 \\
\hline & Pastures subsidy & 0,18 & 0,07 & 0,08 & 0,23 & 0,48 & 0,07 & 0,28 & 0,19 \\
\hline \multirow{2}{*}{$\begin{array}{l}\text { SOCIO- } \\
\text { ECONOMIC } \\
\text { ASPECTS }\end{array}$} & Job opportunities & 0,02 & 0,02 & 0,01 & 0,14 & 0,19 & 0,03 & 0,03 & 0,05 \\
\hline & Pastoral tradition & 0,03 & 0,05 & 0,03 & 0,29 & 0,20 & 0,03 & 0,03 & 0,07 \\
\hline $\begin{array}{l}\text { ATMOSPHERIC } \\
\text { CONTAMINATION }\end{array}$ & Atmospheric emissions... & 0,22 & 0,39 & 0,45 & 0,09 & 0,10 & 0,24 & 0,23 & 0,26 \\
\hline \multirow{2}{*}{$\begin{array}{l}\text { WATER } \\
\text { CONTAMINATION }\end{array}$} & $\begin{array}{l}\text { Underground water } \\
\text { contamination }\end{array}$ & 0,18 & 0,13 & 0,14 & 0,03 & 0,05 & 0,13 & 0,16 & 0,12 \\
\hline & $\begin{array}{l}\text { Surface water } \\
\text { contamination }\end{array}$ & 0,24 & 0,17 & 0,17 & 0,06 & 0,09 & 0,24 & 0,20 & 0,18 \\
\hline \multirow{2}{*}{$\begin{array}{l}\text { OWNERSHIP } \\
\text { RIGHTS }\end{array}$} & Delimitation of the park & 0,02 & 0,03 & 0,02 & 0,13 & 0,14 & 0,03 & 0,02 & 0,05 \\
\hline & Land ownership & 0,02 & 0,02 & 0,01 & 0,14 & 0,12 & 0,01 & 0,02 & 0,03 \\
\hline \multirow{3}{*}{$\begin{array}{l}\text { SOIL } \\
\text { DEGRADATION }\end{array}$} & Soil compaction & 0,06 & 0,03 & 0,05 & 0,03 & 0,01 & 0,07 & 0,03 & 0,04 \\
\hline & Erosion & 0,09 & 0,07 & 0,04 & 0,04 & 0,04 & 0,08 & 0,11 & 0,08 \\
\hline & Loss vegetal cover & 0,11 & 0,10 & 0,07 & 0,05 & 0,07 & 0,15 & 0,18 & 0,12 \\
\hline
\end{tabular}

\subsection{Discussion}

As depicted in the individual diagrams (Figure 3), the stakeholders hold very different points of view about the criteria regarding grazing. Thus, the parkguard considers the criteria "surface water contamination" (24\%) and "atmospheric emissions due to pasture burning" (22\%) as the most important. The natural areas expert considers the criteria "surface water contamination" (24\%) and "atmospheric emissions due to pasture burning" (24\%) as the most important. The environmental researcher considers most important the criteria "atmospheric emissions due to pasture burning" (23\%) and "surface water contamination" (20\%). The tourist operator considers the criteria "atmospheric emissions due to pasture burning" (39\%) and surface water contamination (17\%) as the most important. The tourist considers the criteria "atmospheric emissions due to pasture burning" (45\%) and "surface water contamination" (17\%) as the most important. For the cattle raiser and neighborhood leader, the criteria most important are different from the previous stakeholders; thus, for them the most important are "pastoral tradition" and "job opportunities and incomes" with 29\%, 14\% and 20\%, 19\% respectively (Table 2). Additionally, in the Figure 3 are presented the individual results of all criteria, where there are two marked tendencies about the importance of the criteria related to the grazing in the CNP. One trend is held by the cattle raiser 
and the neighborhood leader who consider the criteria "pastoral tradition" (maximum 29\%) and "job opportunities and incomes" (maximum 20\%) as the most important; the other trend is held by the other 5 stakeholders who consider the criteria "atmospheric emissions due to pasture burning" (maximum 45\%) and "surface water contamination" (maximum 24\%) as the most important.
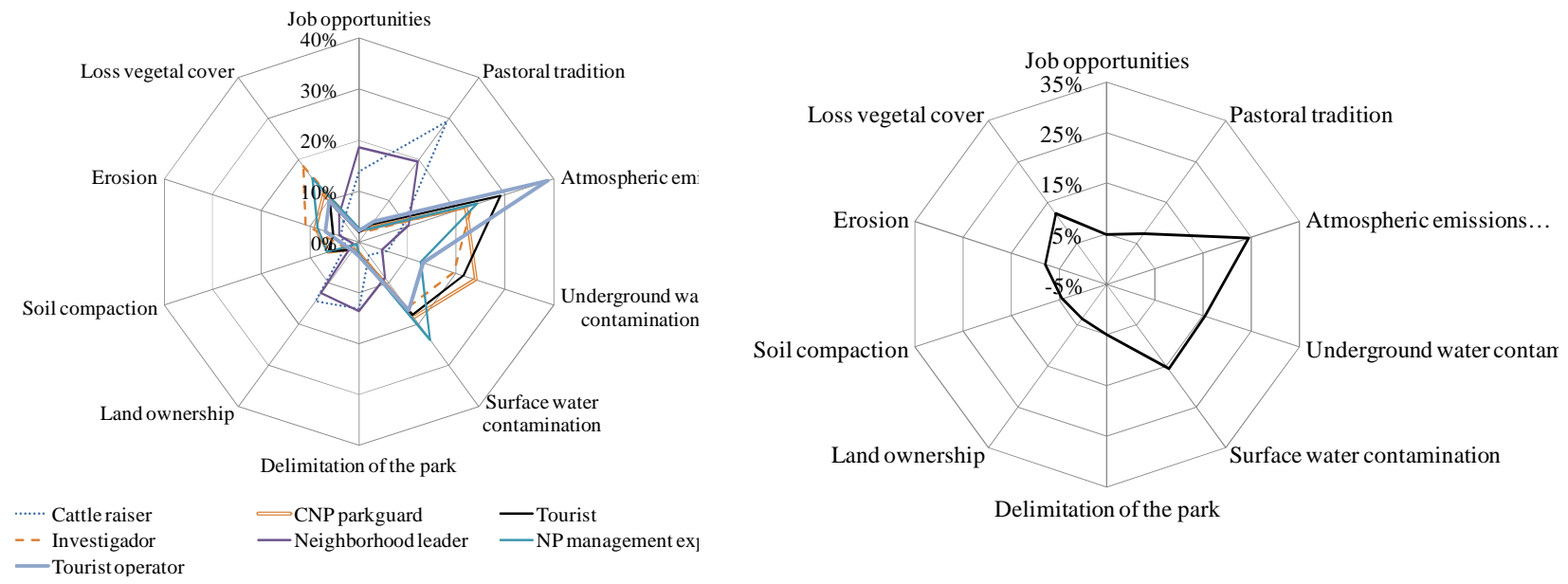

Figure 3. Criteria preference by stakeholder and aggregated.

And the results for the alternatives ranking are shown in Figure 4.
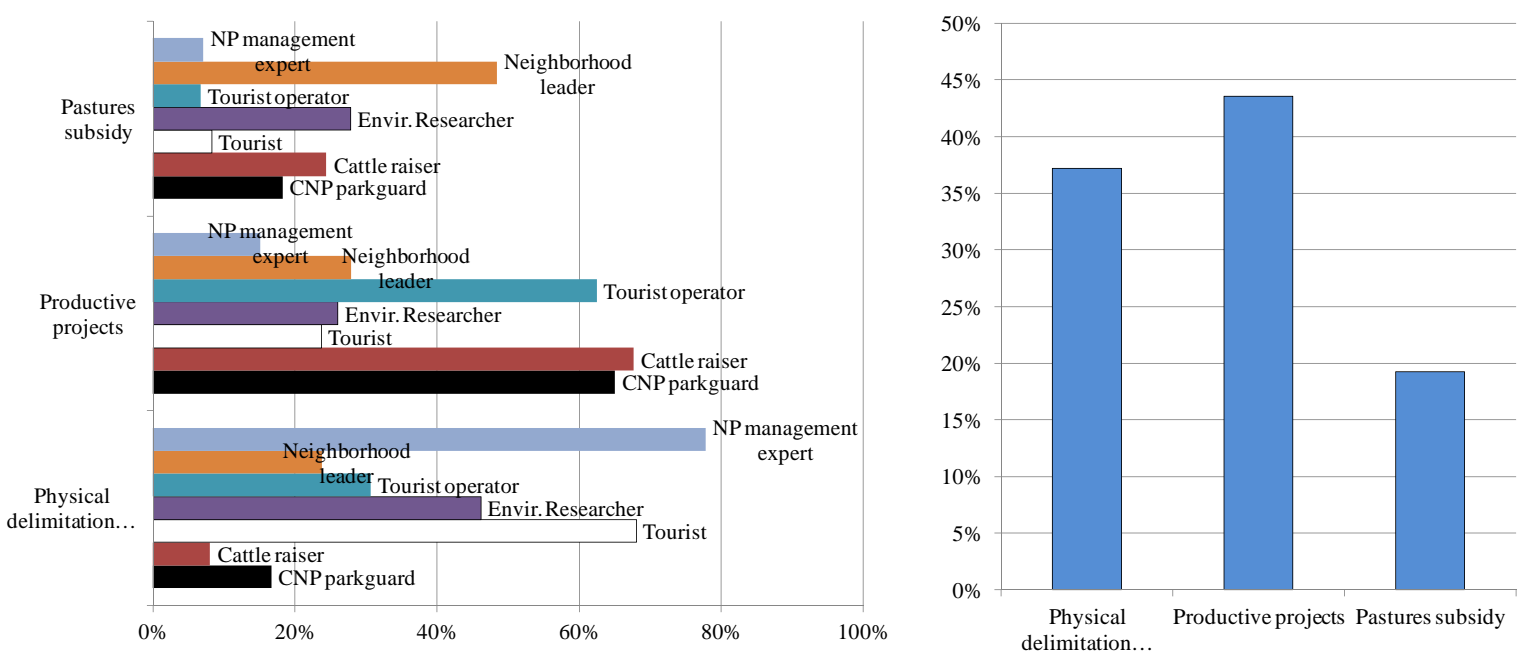

Figure 4. Alternatives preferences by stakeholder and aggregated.

In figure 4 the results of the solution alternatives by stakeholders are presented. The alternative "productive projects opportunities" is preferred by the cattle raiser (69\%); the alternative "physical delimitation of the park and livestock entering control" is preferred by the expert in natural areas (78\%), and the alternative "pastures subsidy" is more preferred by the local neighborhood leader (48\%). The solution alternatives obtained by using the ANP model, are presented in the Figure 4. Thus, the alternatives prioritization obtained after the global judgments aggregation, is as follows: productive projects opportunities (44\%), physical delimitation of the park and livestock entering control" (37\%), and "pastures subsidy" was less preferred (19\%). 


\section{Conclusions}

This paper presents a new approach for the efficient and reliable assessment of grazing in protected natural areas, based on sustainable criteria. The proposed methodology allows elaborating a decision model based on the participation of all involved stakeholders. The methodology allowed combining different sustainable criteria (which were clustered according to their characteristics) and taking into account the judgements of the most involved stakeholders who exert a great influence in the sustainable management of the national park.

The selected solution alternatives should be taken into account by the Environmental Minestry of Ecuador in order to carry out a management plan of the Cotopaxi National Park which includes the participation of all stakeholders especially those who do not agree with the selected strategies. Such a management plan should include some productive projects alternatives such as: ecologic tourism, tourist guides, lodge, food and transport services, handicraft manufacturing, environmental training, and so on.

On the other hand, in the application of this model, there was an agreement among the stakeholders about the final evaluation of the strategies prioritization to solve the grazing and its impacts in the CNP. Thus, the execution of the suggested solution alternatives by the Ecuadorian environmental authorities by means of the park administration will be more effective and guarantee a greater success in the sustainable management of this protected natural area. Although the methodology satisfied the experts as well as the decision makers, the ANP procedure was not free of criticism. During the ANP application to the case study some difficulties showed. For example, complexity of the ANP comparisons were observed. Hence, the questionnaires must be carefully designed and the comparison process must be helped by a facilitator. Despite these difficulties, the results obtained in this work allow us to conclude that ANP is a suitable tool for assessing the grazing and its sustainable strategies in the Cotopaxi National Park. Although the new proposal has been specifically applied to the CNP, this tool can be adapted to any type of sustainability decision-making problem, provided the criteria are properly identified and there are some dependencies among them.

\section{REFERENCES}

Agnoletti, M. 2007, "The degradation of traditional landscape in a mountain area of Tuscany during the 19th and 20th centuries: Implications for biodiversity and sustainable management". Forest Ecology and Management, Volume 249, Issues 1-2, Pages 5-17

Barkmann, J., K. Glenk, et al. 2008. 'Confronting unfamiliarity with ecosystem functions: The case for an ecosystem service approach to environmental valuation with stated preference methods,' Ecological Economics, Volume 65, Issue 1, 15: 48-62

Blanco Sepúlveda, R., Nieuwenhuyse, A. 2011, "Influence of topographic and edaphic factors on vulnerability to soil degradation due to cattle grazing in humid tropical mountains in northern Honduras CATENA", Volume 86, Issue 2, Pages 130-137

Coello, F. et al., 2007. Actualización del Plan de Manejo del Parque Nacional Cotopaxi. Instituto Ecuatoriano Forestal y de Áreas Naturales y Vida Silvestre, INEFAN, Quito - Ecuador.

Erdoğmuş, Ş.; Aras, H.; Koc, E. 2006. Evaluation of alternative fuels for residential heating in Turkey using analytic network process (ANP) with group decision-making, Renewable and Sustainable Energy Reviews 10: 269-279.

Gómez-Navarro, T.; Garcia-Melon, M.; Acuna-Dutra, S.; Diaz-Martin, D. 2009. An environmental pressure index proposal for urban development planning based on the analytic network process, Environmental Impact Assessment Review 29(5): 319-329. doi:10.1016/j.eiar.2008.10.004 
Himley M., 2009, Nature conservation, rural livelihoods, and territorial control in Andean Ecuador Geoforum, Volume 40, Issue 5, September 2009, Pages 832-842

López-i-Gelats, F., et al. 2011, Is farming enough in mountain areas? Farm diversification in the Pyrenees. Land Use Policy, Volume 28, Issue 4, Pages 783-791

MacLeod, N.D., McIvor, J.G., 2006 Reconciling economic and ecological conflicts for sustained management of grazing lands. Ecological Economics, Volume 56, Issue 3, 15 March 2006, Pages 386401

Nunes, A.N., et al. 2011 Impacts of land use and cover type on runoff and soil erosion in a marginal area of Portugal Applied Geography, Volume 31, Issue 2, Pages 687-699

Partovi, F. Y.; Corredoira, R. A. 2002. Quality function deployment for the good of soccer, European Journal of Operational Research 137(3): 642-656. doi:10.1016/S0377-2217(01)00072-8

Peris-Blanes J., García-Melón M., Gómez-Navarro T., Calabuig C., 'Prioritising local agenda 21 programmes using analytic network process. A Spanish case study', Sustainable development, in press 2011, DOI 10.1002/sd514

Pugh, J., Sarmiento, F.O. 2004, Selling the Public on Sustainable Watershed Conservation, Bulletin of Latin American Research, Vol. 23, No. 3, pp. 303-318

Quiroga, A., et al. 2009, Grazing effect on soil properties in conventional and no-till systems Soil and Tillage Research, Volume 105, Issue 1, Pages 164-170

Reed, M. S.; Fraser, E. D. G.; Dougill, A. J. 2006. An adaptative learning process for developing and applying sustainability indicators with local communities, Ecological Economics 59(4): 406-418.

Saaty, Th., 2001, The Analytic Network Process. Decision Making with interdependence and feedback. RWS Publications. Pittsburgh

Savadogo, P. et al. 2007, Effects of grazing intensity and prescribed fire on soil physical and hydrological properties and pasture yield in the savanna woodlands of Burkina Faso Agriculture, Ecosystems \& Environment, Volume 118, Issues 1-4, Pages 80-92

Solomon, T.B., et al. 2007, Cattle-rangeland management practices and perceptions of pastoralists towards rangeland degradation in the Borana zone of southern Ethiopia Journal of Environmental Management, Volume 82, Issue 4, Pages 481-494

Strauch, A.M., et al. 2009, Impact of livestock management on water quality and streambank structure in a semi-arid, African ecosystem. Journal of Arid Environments, Volume 73, Issue 9, Pages 795-803

Teague, W.R., et al. 2011 Grazing management impacts on vegetation, soil biota and soil chemical, physical and hydrological properties in tall grass prairie. Agriculture, Ecosystems \& Environment, Volume 141, Issues 3-4, Pages 310-322

Williams, K., 2011 Relative acceptance of traditional and non-traditional rural land uses: Views of residents in two regions, southern Australia Landscape and Urban Planning, Volume 103, Issue 1, 30 Pages 55-63 